\title{
Environmental Regulation of Carbohydrate Metabolism by Streptococcus sanguis NCTC 7865 Grown in a Chemostat
}

\author{
By PHILIP D. MARSH, ${ }^{*}$ ANN S. MCDERMID, C. WILLIAM KEEVIL AND \\ DEREK C. ELLWOOD \\ Pathogenic Microbes Research Laboratory, PHLS Centre for Applied Microbiology and \\ Research, Porton Down, Salisbury, Wiltshire SP4 OJG, UK
}

(Received 6 March 1985 ; revised 21 May 1985)

\begin{abstract}
Carbohydrate metabolism by the oral bacterium Streptococcus sanguis NCTC 7865 was studied using cells grown in a chemostat at $\mathrm{pH} 7.0$ under glucose or amino acid limitation (glucose excess) over a range of growth rates $\left(D=0.05 \mathrm{~h}^{-1}-0.4 \mathrm{~h}^{-1}\right)$. A mixed pattern of fermentation products was always produced although higher concentrations of lactate were formed under amino acid limitation. Analysis of culture filtrates showed that arginine was depleted from the medium under all conditions of growth; a further supplement of $10 \mathrm{~mm}$-arginine was also consumed but did not affect cell yields, suggesting that it was not limiting growth. Except at the slowest growth rate $\left(D=0.05 \mathrm{~h}^{-1}\right)$ under glucose limitation, the activity of the glucose phosphotransferase (PTS) system was insufficient to account for the glucose consumed during growth, emphasizing the importance of an alternative method of hexose transport in the metabolism of oral streptococci. The PTS for a number of sugars was constitutive in $S$. sanguis NCTC 7865 and, even though the cells were grown in the presence of glucose, the activity of the sucrose-PTS was highest. The glycolytic activity of cells harvested from the chemostat was affected by the substrate, the $\mathrm{pH}$ of the environment, and their original conditions of growth. Glucose-limited cells produced more acid than those grown under conditions of glucose excess; at slow growth rates, in particular, greater activities were obtained with sucrose compared with glucose or fructose. Maximum rates of glycolytic activity were obtained at $\mathrm{pH} 8.0$ (except for

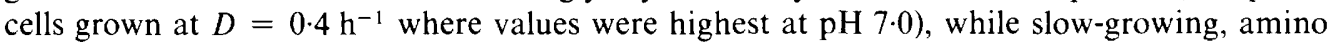
acid-limited cells could not metabolize at $\mathrm{pH} 5 \cdot 0$. These results are discussed in terms of their possible significance in the ecology of dental plaque and the possible involvement of these bacteria in the initiation but not the clinical progression of a carious lesion.
\end{abstract}

\section{INTRODUCTION}

Streptococci can be readily isolated from all surfaces in the mouth and comprise a large proportion (approximately $28 \%$ ) of the total cultivable flora of dental plaque (see Marsh \& Martin, 1984). Oral streptococci can be separated into several distinct species, the numbers of which vary from site to site in both healthy and diseased mouths. For example, while Streptococcus sanguis is commonly present in relatively high numbers on healthy enamel surfaces, Streptococcus mutans is irregularly isolated and is normally only a minor component of dental plaque, except at sites which develop dental caries (for examples see Hardie et al., 1977; Huis in t'Veld et al., 1979; Loesche \& Straffon, 1979).

The association between $S$. mutans and human dental caries has resulted in a considerable amount of research on the properties relating to the cariogenicity of this group of bacteria. Included among these properties are the ability to ferment rapidly to acid a number of dietary carbohydrates, the ability to tolerate and continue to metabolize sugars in the low $\mathrm{pH}$

Abbreviations: PEP, phosphoenolpyruvate; PTS, phosphotransferase. 
environments so produced, and the production of copious quantities of water-insoluble polysaccharides from sucrose which are involved in consolidating the attachment of cells to enamel and to one another, and which may contribute to the localization of acidic fermentation products (for reviews see Van Houte, 1980; Marsh \& Martin, 1984). On the other hand, although $S$. mutans undoubtedly plays a major role in dental caries, lesions can sometimes develop in the absence of this species (Hardie et al., 1977; Huis in t'Veld et al., 1979; Loesche \& Straffon, 1979). Furthermore, other oral bacteria can produce caries, albeit usually to a lesser extent than $S$. mutans, in experimental animals (Drucker \& Green, 1981) but much less is known about the metabolism of these organisms. Consequently, we have undertaken a study of the growth and carbohydrate metabolism of a representative strain of $S$. sanguis, a species that can act as an opportunistic pathogen, for example when gaining entry to the blood stream following a tooth extraction, but which is not generally considered to play a major role in the aetiology of dental caries in man. Cells were grown in a chemostat under a range of environmental conditions to closely simulate their behaviour in the mouth. Results relating to the production of extracellular polysaccharides have been published previously (Keevil et al., 1983, 1984b; West et al., 1984).

\section{METHODS}

Bacterial strain and growth conditions. Streptococcus sanguis NCTC 7865 was grown under glucose (55.6 mM) or amino acid limitation (glucose excess, $166.7 \mathrm{~mm}$ ) at $37^{\circ} \mathrm{C}$ in a chemostat with a $550 \mathrm{ml}$ working capacity using a modified (Marsh et al., 1982), filter-sterilized, chemically defined medium (Carlsson, 1970). The pH was maintained automatically at $7 \cdot 0 \pm 0 \cdot 1$ by the addition of $2 \mathrm{M}-\mathrm{NaOH}$, and the gas phase was $95 \% \mathrm{~N}_{2}$ and $5 \% \mathrm{CO}_{2}$ (flow rate $160 \mathrm{ml} \mathrm{min}^{-1}$ ). The cells were grown at dilution rates $(D)$ of $0.05,0 \cdot 1,0.2$ and $0.4 \mathrm{~h}^{-1}$, which correspond to mean generation times of $13 \cdot 9,6 \cdot 9,3.5$ and $1 \cdot 7 \mathrm{~h}$, respectively. Each culture was allowed to reach equilibrium for at least 10 mean generation times before harvesting.

Cell preparation. Cells were collected during steady-state conditions via the chemostat overflow into a container cooled in ice, and were harvested by centrifugation $(8000 \mathrm{~g}$ for $10 \mathrm{~min})$. Cells were washed with $200 \mathrm{mM}-\mathrm{KCl}$ and centrifuged twice $(8000 \mathrm{~g}$ for $10 \mathrm{~min}$ ) and resuspended in $200 \mathrm{~mm}-\mathrm{KCl}$ to give approximately $30 \mathrm{mg}(\mathrm{dry}$ wt) cells $\mathrm{ml}^{-1}$, and were stored on ice until used.

Dry weight measurement. Known volumes of washed cells were filtered through pre-dried, pre-weighed polycarbonate membrane filters, pore size $0.4 \mu \mathrm{m}$ (Sterilin). The cells on the filters were washed twice with sterile distilled water, and the filters were heated for $2 \mathrm{~min}$ to constant weight in a microwave oven. Estimations were done in duplicate and dry weights were calculated by differential weighing.

Glycolytic activity by washed cells. Washed cells were further diluted to give a final cell concentration of $5 \mathrm{mg}$ (dry wt) $\mathrm{ml}^{-1}$ in $5 \mathrm{ml} 200 \mathrm{~mm}-\mathrm{KCl}$. Acid production by these cells from storage material (endogenous metabolism) and after a pulse of glucose, sucrose or fructose at $3 \mathrm{~mm}$ was measured at $37^{\circ} \mathrm{C}$ under a constant flow of $\mathrm{O}_{2}-\mathrm{free}_{2} \mathrm{~N}_{2}$ in a

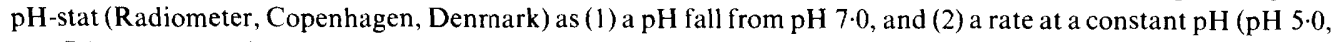
$6.0,7.0$ and 8.0 ) using $0.1 \mathrm{M}-\mathrm{KOH}$ as the titrant. Rates of glycolytic activity were expressed as nmol acid neutralized $\min ^{-1}$ (mg cell dry wt) ${ }^{-1}$ (Marsh et al., 1982).

Assay for phosphoenolpyruvate-phosphotransferase (PEP-PTS) activity. Sugar transport via the PEP-PTS system was assayed with whole cells made permeable by adding 0.01 vol. toluene. The assay mixture and toluene treatment were as described by Hamilton \& Ellwood (1978). Net activity was expressed as nmol pyruvate formed $\min ^{-1}(\mathrm{mg} \text { cell dry } w \mathrm{t})^{-1}$.

Rate of glucose transport in the chemostat. Glucose uptake by cells growing in each chemostat was calculated from the equation of Herbert \& Kornberg (1976):

$$
q_{\mathrm{s}}=D\left(S_{0}-S\right) /(x \times 60)
$$

where $q_{\mathrm{s}}=$ rate of glucose utilization [ $\mathrm{nmol}(\mathrm{mg} \text { cell dry } \mathrm{wt})^{-1}$ ], $D=$ dilution rate $\left(\mathrm{h}^{-1}\right), S_{0}=$ glucose concentration in the inflowing medium (nmol ml-1), $S=$ glucose concentration in the culture supernatant (nmol ml-1) and $x=$ community dry weight $\left(\mathrm{mg} \mathrm{ml}^{-1}\right.$ ).

Rate of acid production in the chemostat. Because $S$. sanguis NCTC 7865 produced acidic fermentation products and because the chemostat cultures were maintained at $\mathrm{pH} 7.0$ by the automatic addition of $2 \mathrm{M}-\mathrm{NaOH}$, it was possible to determine the rate of acid production from the equation of Keevil et al. (1984a):

$$
q_{\text {acid }}=A D_{\text {acid }} / 60 x
$$

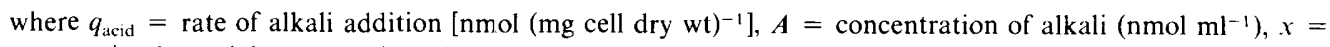
community dry weight $\left(\mathrm{mg} \mathrm{ml}^{-1}\right)$ and $D_{\text {acid }}=$ dilution rate for acid (volume of alkali added per h per volume of culture vessel). 
Analytical procedures. Amino acids in the uninoculated medium and the culture supernatant were analysed regularly as described previously, together with a measurement of the residual glucose and culture turbidity (F.llwood $e t a l ., 1974$ ). Culture filtrates were analysed for volatile and non-volatile acid products of fermentation by the methods of Hamilton \& Ellwood (1978).

\section{RESULTS}

\section{Growth parameters in the chemostat}

At all growth rates, glucose could not be detected in the culture filtrates from the glucoselimited chemostat, while glucose was always present in supernatants from the amino acidlimited chemostat (Table 1). Arginine was depleted from the medium under both glucoselimited and glucose-excess conditions (Table 2). However, it was not limiting the growth of $S$. sanguis NCTC 7865 under glucose limitation since a further addition of $10 \mathrm{~mm}$-arginine did not significantly increase the cell yield (Table 3 ). Molar growth yields were two- to threefold higher under glucose limitation compared to glucose excess conditions (Table 1). Although values are cited as $Y_{\text {molar glucose }}$, arginine could also have been acting as a carbon and energy source by providing carbamyl phosphate for substrate level phosphorylation. The increase in concentration of ornithine in culture supernatants after a $10 \mathrm{~mm}$ pulse of arginine provided some experimental support for this proposal (Table 3).

A mixed pattern of fermentation products was formed under all conditions of growth (Table 1). The concentration of lactate in culture filtrates together with the percentage of glucose carbon recovered as fermentation products increased with the dilution rate under glucose limitation, while the highest concentration of lactate was formed at the slowest growth rate under glucose excess conditions. Under all conditions of growth, the percentage of carbon recovered as fermentation products was less than $100 \%$ (Table 1), suggesting that considerable quantities of storage material were being produced.

The rates of glucose consumption and acid production increased with the dilution rate under glucose and amino acid limitation (Fig. 1). In contrast, the activity of the PEP-mediated glucosePTS remained constant or decreased slightly as the growth rate increased. Except at the slowest rate of growth $\left(D=0.05 \mathrm{~h}^{-1}\right)$ under glucose limitation, the activity of the PTS was not commensurate with the measured rate of glucose utilization in the chemostat (Fig. 1).

\section{Glycolytic and PTS activity of washed cells}

The response of cells harvested from the chemostat to a pulse of carbohydrate was measured in terms of the activity of their PEP-PTS transport systems and their ability to convert these sugars to acidic fermentation products. A comparison was also made of the glycolytic activity of cells metabolizing polymers stored intracellularly during growth (endogenous metabolism). Glycolytic activity was measured as the terminal pH after $15 \mathrm{~min}$ metabolism (Table 4) and as a rate at a constant $\mathrm{pH}$ (Table 5, Fig. 2). Significant endogenous metabolism was measured in all cells irrespective of the conditions of growth but, perhaps surprisingly, some of the highest activities were found with cells that had been grown under glucose limitation (Tables 4 and 5). Cells grown under glucose limitation always produced more acid from a pulse of glucose than those grown under amino acid limitation but this relationship did not hold for sucrose and fructose. Indeed, the lowest terminal $\mathrm{pH}$ value and the fastest rate of acid production were obtained from amino acid-limited cells grown at $D=0.05 \mathrm{~h}^{-1}$ and metabolizing sucrose (Tables 4 and 5). In general, fructose was metabolized more slowly than the other two sugars. These results reflected the measured activities of the PTS under different growth conditions. Growth rate had little effect on the glucose-PTS above $D=0.1 \mathrm{~h}^{-1}$ (Fig. 1) but the activity of the glucose-, sucrose- and fructose-PTS was greater in cells grown under carbohydrate limitation. At $D=0 \cdot 1 \mathrm{~h}^{-1}$, in spite of the cells being grown on glucose, the activity of the sucrose-PTS was approximately twice that for glucose; activities for the glucose-, sucrose- and fructose-PTS were $22 \cdot 5,55 \cdot 0$ and $9.8 \mathrm{nmol}(\mathrm{mg} \text { cell dry } \mathrm{wt})^{-1} \mathrm{~min}^{-1}$, respectively, under glucose limitation and 13.4 , 25.5 and $4.0 \mathrm{nmol}(\mathrm{mg} \text { cell dry } \mathrm{wt})^{-1} \mathrm{~min}^{-1}$, respectively, under glucose excess conditions. 


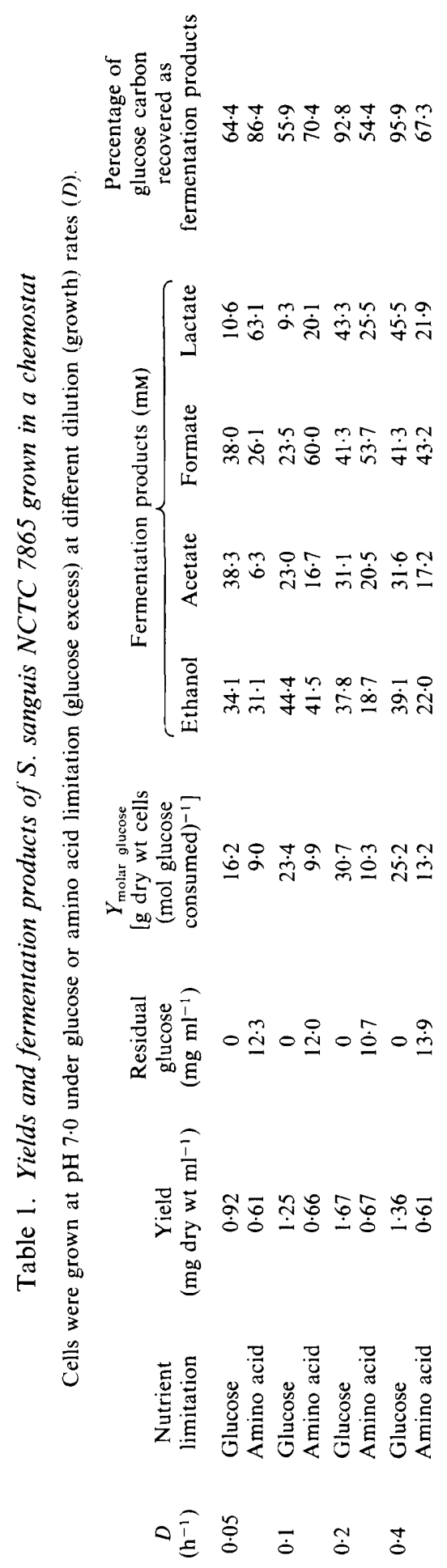



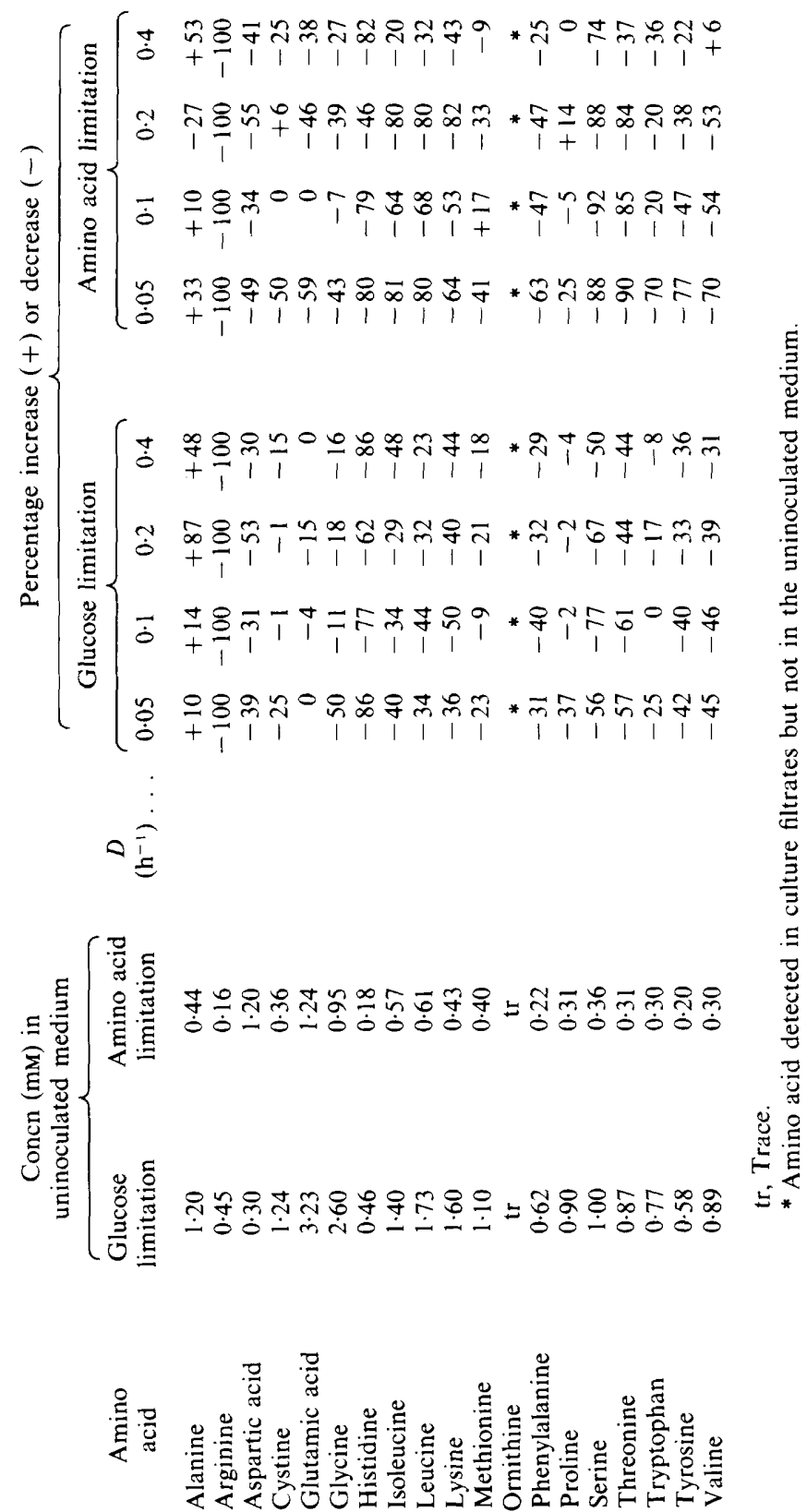

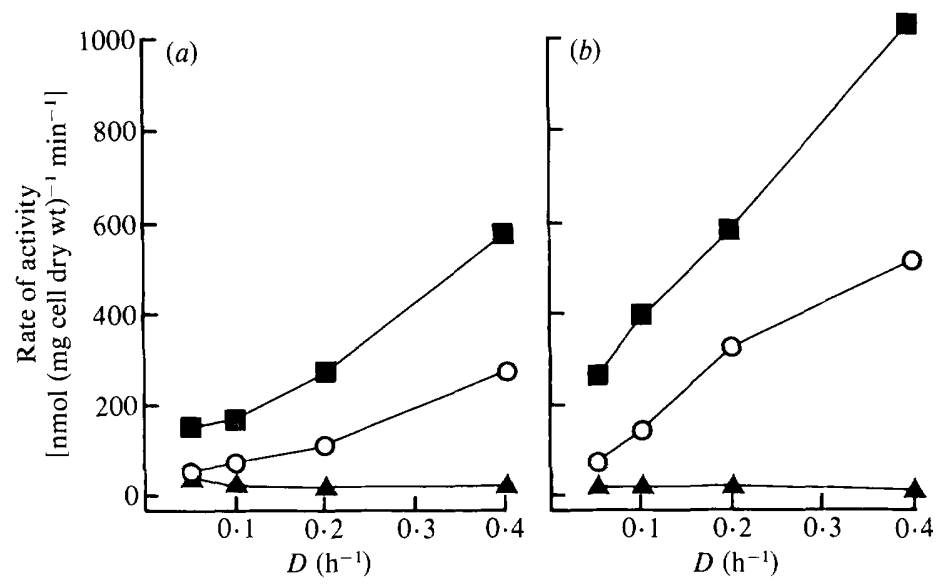

Fig. 1. A comparison of the rates of glucose consumption $\left(q_{\mathrm{s}}, \mathrm{O}\right)$ and acid production $\left(q_{\mathrm{acid}}, \mathbf{\square}\right)$ by $S$. sanguis NCTC 7865 grown in a chemostat at different growth rates under $(a)$ glucose limitation or (b) amino acid limitation. The activity of the glucose-PTS $(\boldsymbol{\Delta})$ is also shown. The activity was measured in cells harvested from the chemostat as described in the text. All rates of activity are expressed as $\mathrm{nmol}$ glucose, acid or pyruvate formed (mg cell dry wt) ${ }^{-1} \mathrm{~min}^{-1}$.

Table 3. Effect on cell yields of supplementing a glucose-limited culture of $S$. sanguis NCTC 7865 with arginine

Cells were grown in a chemically defined medium (M3) at $\mathrm{pH} 7 \cdot 0$ and at a dilution rate of $0 \cdot 1 \mathrm{~h}^{-1}$.

\begin{tabular}{|c|c|c|c|c|c|c|}
\hline \multirow[b]{2}{*}{$\begin{array}{l}\text { Growth } \\
\text { medium }\end{array}$} & \multicolumn{2}{|c|}{ Arginine $(\mathrm{mM})$ in: } & \multicolumn{2}{|c|}{ Ornithine $(\mathrm{mm})$ in : } & \multirow[b]{2}{*}{$\begin{array}{l}\mathrm{OD}_{540} \text { of } \\
\text { culture* }\end{array}$} & \multirow[b]{2}{*}{$\begin{array}{c}\text { Cell yield* } \\
\text { (mg dry wt } \mathrm{ml}^{-1} \text { ) }\end{array}$} \\
\hline & Medium & $\begin{array}{l}\text { Culture } \\
\text { filtrate }\end{array}$ & Medium & $\begin{array}{l}\text { Culture } \\
\text { filtrate }\end{array}$ & & \\
\hline M3 & 0.45 & 0 & 0.02 & $0 \cdot 28$ & $3.20 \pm 0.29(7)$ & $1 \cdot 20$ \\
\hline $\begin{array}{l}\mathrm{M} 3+ \\
10 \mathrm{mM} \text {-arginine }\end{array}$ & $10 \cdot 45$ & 0 & 0.02 & $3 \cdot 20$ & $3.40 \pm 0.29(9)$ & $1 \cdot 22 \pm 0.01(2)$ \\
\hline
\end{tabular}

* Results are expressed as mean $\pm S D$ with the number of experiments in parentheses.

\section{Table 4. Acid production by S. sanguis NCTC 7865}

Cells were grown in a chemostat at pH 7.0 under glucose or amino acid limitation (glucose excess) at different dilution rates $(D)$. Cells were harvested by centrifugation, and were washed and resuspended in $200 \mathrm{~mm}-\mathrm{KCl}$. Acid production was measured as a $\mathrm{pH}$ fall from $\mathrm{pH} 7.0$ after 15 min endogenous metabolism of storage material, or after a pulse of excess glucose, sucrose or fructose. The number of determinations using fresh cells prepared on different days is given in parentheses.

\begin{tabular}{clcccc}
$D$ & \multicolumn{4}{c}{ Terminal pH (mean $\pm \mathrm{sD})$} \\
$\left(\mathrm{h}^{-1}\right)$ & $\begin{array}{c}\text { Nutrient } \\
\text { limitation }\end{array}$ & $\overbrace{\text { Endogenous }}$ & Glucose & Sucrose & Fructose \\
0.05 & Glucose & $5.61 \pm 0.18(4)$ & $4.87 \pm 0.07(5)$ & $4.81 \pm 0.03(4)$ & $5.04 \pm 0.11(3)$ \\
& Amino acid & $6.10 \pm 0.06(3)$ & $5.64 \pm 0.28(3)$ & $4.27 \pm 0.25(3)$ & $4.89 \pm 0.30(3)$ \\
0.1 & Glucose & $5.94 \pm 0.04(3)$ & $4.54 \pm 0.09(4)$ & $4.58 \pm 0.08(3)$ & $4.80 \pm 0.06(3)$ \\
& Amino acid & $5.13 \pm 0.20(7)$ & $5.00 \pm 0.19(9)$ & $4.72 \pm 0.08(5)$ & $4.93 \pm 0.10(4)$ \\
0.2 & Glucose & $5.20 \pm 0.26(3)$ & $4.49 \pm 0.15(3)$ & $4.65 \pm 0.15(3)$ & $4.70 \pm 0.05(3)$ \\
& Amino acid & $6.00 \pm 0.09(4)$ & $4.66 \pm 0.11(4)$ & $4.74 \pm 0.11(4)$ & $5.26 \pm 0.21(4)$ \\
0.4 & Glucose & $5.47 \pm 0.23(3)$ & $4.63 \pm 0.10(3)$ & $4.82 \pm 0.08(3)$ & $4.88 \pm 0.11(3)$ \\
& Amino acid & $6.30 \pm 0.28(4)$ & $4.73 \pm 0.08(4)$ & $4.57 \pm 0.03(3)$ & $4.88 \pm 0.18(4)$
\end{tabular}




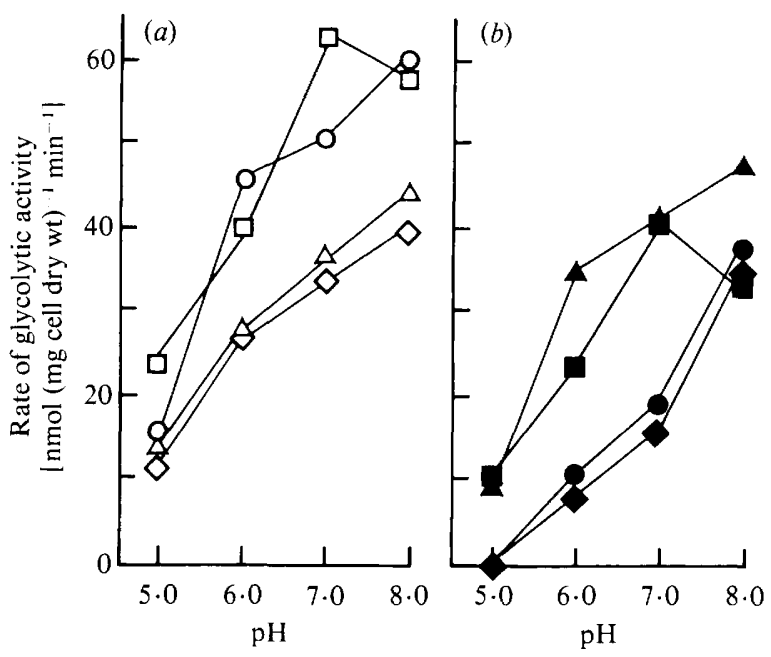

Fig. 2. Glycolytic activity of KCl-washed cells of $S$. sanguis NCTC 7865 harvested from a chemostat at different dilution rates $\left(\diamond, \bullet, 0.05 \mathrm{~h}^{-1} ; \bigcirc, \odot, 0 \cdot 1 \mathrm{~h}^{-1} ; \triangle, \Delta, 0.2 \mathrm{~h}^{-1} ; \square, \boldsymbol{\square}, 0.4 \mathrm{~h}^{-1}\right)$, and measured in a pH-stat at different $\mathrm{pH}$ values. Cells were grown under $(a)$ glucose limitation or $(b)$ amino acid limitation. Rates of glycolytic activity are expressed as nmol acid neutralized (mg cell dry $\mathrm{wt})^{-1} \mathrm{~min}^{-1}$.

\section{Table 5. Glycolytic activity of S. sanguis NCTC 7865}

Cells were grown in a chemostat at $\mathrm{pH} 7.0$ under glucose or amino acid limitation (glucose excess) at different dilution rates $(D)$. Cells were harvested by centrifugation, and were washed and resuspended in $200 \mathrm{~mm}-\mathrm{KCl}$. Glycolytic activity was measured as a rate at $\mathrm{pH} 7.0$ from the endogenous metabolism of storage material, or after a pulse of excess glucose, sucrose or fructose. Units of glycolytic activity are nmol acid neutralized at $\mathrm{pH} 7.0\left(\mathrm{mg}\right.$ cell dry wt) ${ }^{-1} \mathrm{~min}^{-1}$. The number of determinations using fresh cells prepared on different days is given in parentheses.

\begin{tabular}{|c|c|c|c|c|c|}
\hline \multirow[b]{2}{*}{$\begin{array}{c}D \\
\left(\mathrm{~h}^{-1}\right)\end{array}$} & \multirow[b]{2}{*}{$\begin{array}{l}\text { Nutrient } \\
\text { limitation }\end{array}$} & \multicolumn{4}{|c|}{ Glycolytic activity (mean $\pm S D$ ) } \\
\hline & & $\begin{array}{l}\text { Endogenous } \\
\text { substrate }\end{array}$ & Glucose & Sucrose & Fructose \\
\hline 0.05 & $\begin{array}{l}\text { Glucose } \\
\text { Amino acid }\end{array}$ & $\begin{array}{l}14 \pm 4(6) \\
20 \pm 2(6)\end{array}$ & $\begin{array}{l}40 \pm 10(6) \\
19 \pm 3(7)\end{array}$ & $\begin{array}{l}31 \pm 11(5) \\
69 \pm 6(2)\end{array}$ & $\begin{array}{l}22 \pm 9(5) \\
39 \pm 10(5)\end{array}$ \\
\hline 0.1 & $\begin{array}{l}\text { Glucose } \\
\text { Amino acid }\end{array}$ & $\begin{array}{r}9 \pm 3(5) \\
19 \pm 1(2)\end{array}$ & $\begin{array}{l}57 \pm 9(5) \\
21 \pm 5(8)\end{array}$ & $\begin{array}{l}50 \pm 12(3) \\
23 \pm 1(4)\end{array}$ & $\begin{array}{l}35 \pm 6(2) \\
19 \pm 4(2)\end{array}$ \\
\hline 0.2 & $\begin{array}{l}\text { Glucose } \\
\text { Amino acid }\end{array}$ & $\begin{array}{l}16 \pm 3(4) \\
10 \pm 4(3)\end{array}$ & $\begin{array}{l}49 \pm 7(4) \\
40 \pm 6(5)\end{array}$ & $\begin{array}{l}53 \pm 10(4) \\
40 \pm 6(3)\end{array}$ & $\begin{array}{l}37 \pm 7(4) \\
22 \pm 1(3)\end{array}$ \\
\hline $0 \cdot 4$ & $\begin{array}{l}\text { Glucose } \\
\text { Amino acid }\end{array}$ & $\begin{array}{l}23 \pm 4(3) \\
10 \pm 2(5)\end{array}$ & $\begin{array}{l}45 \pm 13(3) \\
41 \pm 9(5)\end{array}$ & $\begin{array}{l}36 \\
41 \pm 1(2)\end{array}$ & $\begin{array}{l}17 \\
24 \pm 3(2)\end{array}$ \\
\hline
\end{tabular}

Although the cells were grown in the chemostat at $\mathrm{pH} 7 \cdot 0$, the maximum glycolytic rates by washed cells were at $\mathrm{pH} 8.0$ except for those grown at $D=0.4 \mathrm{~h}^{-1}$ (Fig. 2). At every pH tested, cells grown under glucose limitation produced acid at a faster rate than cells grown under amino acid limitation. Also, glucose-limited cells were more aciduric, i.e. they could continue to metabolize at lower external $\mathrm{pH}$ values, than those grown under amino acid limitation (Fig. 2). Indeed, only the faster-growing cells $\left(D=0.2\right.$ and $\left.0.4 \mathrm{~h}^{-1}\right)$ from the amino acid-limited chemostat could metabolize glucose at $\mathrm{pH} 5 \cdot 0$.

\section{DISCUSSION}

Until recently, the PEP-PTS was believed to be the sole sugar transport system in oral streptococci. However, in the present study, it was clear that, except at $D=0.05 \mathrm{~h}^{-1}$ under glucose limitation, the activity of the PTS was insufficient to account for the concentration of 
glucose being transported by $S$. sanguis during growth. Similar results have been reported for $S$. mutans catabolizing glucose (Ellwood et al., 1979) and sucrose (Ellwood \& Hamilton, 1982), and for Actinomyces viscosus growing on glucose (Hamilton \& Ellwood, 1983). Recent studies, using a PTS-defective mutant of $S$. mutans (Hamilton \& St Martin, 1982) and a range of streptococci in which the PTS was inhibited by chlorhexidine (Keevil et al., 1984c; Marsh et al., 1984), have shown that the residual, non-PTS attributable glycolytic activity could be completely abolished by protonophores such as gramicidin and by the ATP synthetase inhibitor $N^{\prime}, N^{\prime}$ dicyclohexylcarbodiimide, suggesting that the additional hexose transport was driven by the energized membrane. The finding that valinomycin had less of an inhibitory effect than gramicidin on both glycolysis (Keevil et al., 1984c) and growth (West et al., 1984) of S. sanguis suggested that $\Delta \mathrm{pH}$ rather than $\Delta \psi$ was the major protonmotive force component responsible for driving glucose transport. The possession of two independent sugar transport systems (PTS and protonmotive-force driven) would enable oral streptococci to respond efficiently to the oscillating $\mathrm{pH}$ and nutrient conditions (particularly in terms of carbohydrate concentration) that prevail in the mouth.

A surprising feature of our study was the significant levels of endogenous metabolism exhibited by cells grown under glucose limitation since, in most bacteria, storage polysaccharides are synthesized only during periods of carbohydrate excess. However, in $S$. sanguis NCTC 7865, a novel reaction has been described whereby glucose can be phosphorylated by acetyl phosphate or carbamyl phosphate directly to glucose 1-phosphate, the precursor of intracellular storage material (Keevil et al., 1984a). The depletion of arginine and the production of acetic acid would have ensured a continual supply of both phosphoryl donors under all growth conditions. The involvement of acetyl phosphate and carbamyl phosphate in substrate level phosphorylation might also account, in part, for the higher than theoretically predicted cell yields of $S$. sanguis NCTC 7865 during glucose-limited growth (Keevil et al., $1984 c$ ). The ability of an organism to synthesize storage material over a range of environmental conditions might also aid its survival in dental plaque since it has been suggested that polysaccharides help to preserve cell integrity and viability during conditions of nutrient starvation, and they can also be used as an energy source in the absence of exogenous carbohydrates (Dawes, 1976). Furthermore, this property may be important in disease since the production of acid by endogenous metabolism in the absence of dietary carbohydrates has been proposed as an important characteristic of cariogenic bacteria (Tanzer et al., 1976).

The pattern of amino acid utilization by $S$. sanguis NCTC 7865 also differed from that reported for other oral bacteria. In the present study, arginine was depleted under all conditions of growth, whereas cysteine and asparagine, respectively, were the predominant amino acids consumed by $S$. mutans (Hamilton \& Ellwood, 1978) and A. viscosus (Hamilton \& Ellwood, 1983). Mixed substrate utilization is a common feature of bacterial communities so that the observed preferences for different amino acids might enable these organisms to avoid competition and co-exist under carbohydrate-limited conditions, as has been observed both in mixed continuous cultures (Marsh et al., 1983; Kemp et al., 1983; McKee et al., 1984) and in dental plaque itself.

Although it is now generally accepted that no single organism is the sole pathogen in dental caries, certain bacteria, in particular S. mutans and Lactobacillus spp. (Hardie et al., 1977; Loesche \& Straffon, 1979), have been identified as having a greater role in the disease process than species such as $S$. sanguis. When comparing cariogenic with non-cariogenic bacteria, properties such as the rate of carbohydrate transport and acid production in response to a pulse of sugar are as important as the terminal $\mathrm{pH}$ reached (enamel demineralization accelerates below $\mathrm{pH} 5 \cdot 5$ ). Furthermore, the type of acid is important in the development of carious lesions in vitro, acetic acid being preferentially adsorbed by enamel (Featherstone et al., 1981; Geddes et al., 1984). The data presented here show that $S$. sanguis NCTC 7865 produces more acetic acid and has a greater endogenous metabolism under certain conditions of growth than does $S$. mutans. The PTS transport system for a number of sugars was constitutive in $S$. sanguis and, unlike the system in S. mutans (St Martin \& Wittenberger, 1979; Slee \& Tanzer, 1980), its activity was less affected by growth conditions. Moreover, under certain environmental 
conditions, the activity of the sucrose-PTS of $S$. sanguis was greater and the terminal pH from sucrose lower than the values obtained with S. mutans (Ellwood et al., 1979; Hamilton \& Ellwood, 1978). Paradoxically, however, the rate of acid production from any sugar was always much slower than the values obtained with $S$. mutans. Another major difference was the inability of $S$. sanguis to produce acid at low $\mathrm{pH}$ values, which is in agreement with recent work by Harper \& Loesche (1984). These findings suggest that $S$. sanguis might have sufficient glycolytic activity to contribute to the early stages of dental caries, although its apparent lack of acid tolerance makes it a less likely candidate for being involved in the clinical progression of a lesion through the enamel to the underlying tissues.

This work was supported in part by a grant from the Medical Research Council (G979/243/SB).

\section{REFERENCES}

CARLSSON. J. (1970). Nutritional requirements of Streptococcus mutans. Caries Research 4. 305-320.

DAwES. E. A. (1976). Endogenous metabolism and the survival of starved prokaryotes. Simposia of the Society for General Microbiology 26, 19-53

Drucker, D. B. \& Green, R. M. (1981). The relative cariogenicity of different streptococci in the gnotobiotic WAG RIJ rat. Archives of Oral Biology 26 , 599-606.

Eliwood, D. C.\& Hamilton, 1. R. (1982). Properties of Streptococcus mutans Ingbritt growing on limiting sucrose in a chemostat: repression of the phosphoenolpyruvate phosphotransferase system. Infection and Immunity 36, 576-581

Ellwood. D. C.. Hunter. J. R. \& Longyear, V. M. C. (1974). Growth of Streptococcus mutans in a chemostat. Archice's of Oral Biology 19, 659-665.

Ellwood, D. C.. Phipps, P. J. \& Hamilton, I. R. (1979). Effect of growth rate and glucose concentration on the activity of the phosphoenolpyruvate phosphotransferase system in Streptococcus mutans Ingbritt grown in continuous culture. Infection and Immunity 23, 224-231.

Featherstone, J. D. B. \& Rodgers. B. E. (1981). Effect of acetic. lactic and other organic acids on the formation of artificial carious lesions. Caries Research 15, 377-385.

Geddes, D. A. M.. Weetman, D. A. \& Featherstone, J. D. B. (1984). Preferential loss of acetic acid from plaque fermentation in the presence of enamel. Caries Research 18, 430-433.

Hamilton, I. R. \& Ellwood, D. C. (1978). Effects of fluoride on carbohydrate metabolism by washed cells of Streptococcus mutans grown at various $\mathrm{pH}$ values in a chemostat. Infection and Immunity 19 , $434-442$

Hamilton, I. R \& Ellwood, D. C. (1983). Carbohydrate metabolism by Actinomyces riscosus growing in continuous culture. Infection and Immunity 42, 19-26.

Hamilton, I. R. \& St Martin, E. J. (1982). Evidence for the involvement of proton motive force in the transport of glucose by a mutant of Streptococcus mutums strain DR 0001 defective in glucose-phosphoenolpyruvate phosphotransferase activity. Infection and Immunity 36. 567-575.

Hardie, J. M.. ThOMSon, P. T., Solth, R. J., Marsh, P. D.. BOWdeN, G. H., MCKeE, A. S., FILlery, E. D. \& SLACK, G. L. (1977). A longitudinal epidemiological study of dental plaque and the development of dental caries - interim results after two years. Journal of Dental Research 56, 90-98.

Harper, D. S. \& Loesche, W. J. (1984). Growth and acid tolerance of human dental plaque bacteria. Archices of Oral Biology 29, 843-848.

Herbert, D. \& Kornberg, H. L. (1976). Glucose transport as a rate-limiting step in the growth of Escherichia coli on glucose. Biochemical Journal 156, 477-480.

Huis in t'Veld, J, van Palenstein-Helderman, W. H. \& BaCKer DiRKs, O. (1979). Streptococcus mutans and dental decay in humans - a bacteriological and immunological study. Antonie van Leeuwenhoek 45, 25-33.

KeEvil, C. W., West, A. A., Marsh, P. D. \& Ellwood, D. C. (1983). Batch versus continuous culture studies of glucosyltransferase synthesis in oral streptococci. In Glucosyltransferase, Glucans, Sucrose and Dental Caries, pp. 189-200. Edited by R. J. Doyle \& J. E. Ciardi. Washington, DC: Information Retrieval.

Keevil, C. W., Marsh, P. D. \& Ellwood, D. C. (1984a). Regulation of glucose metabolism in oral streptococci through independent pathways of glucose 6-phosphate and glucose 1-phosphate formation. Journal of Bacteriology 157, 560-567.

KeEvil, C. W., West, A. A., Bourne, N. \& Marsh, P. D. $(1984 b)$. Inhibition of the synthesis and secretion of extracellular glucosyl- and fructosyltransferase in Streptococcus sanguis by sodium ions. Journal of General Microbiology 130, 77-82.

Keevil, C. W., Williamson, M. I., Marsh, P. D. \& Ellwood, D. C. (1984c). Evidence that glucose and sucrose uptake in oral streptococcal bacteria involves independent phosphotransferase and protonmotive force-mediated mechanisms. Archives of Oral Biology 29, 871-878.

Kemp, C. W., Robrish, S. A., Curtis, M. A., Sharer, S. A. \& Bowen, W. H. (1983). Application of a competition model to the growth of Streptococcus mutans and Streptococcus sanguis in binary continuous culture. Applied and Environmental Microbiology 45, $1277-1282$.

Loesche, W. J. \& Straffon, L. H. (1979). Longitudinal investigations of the role of Streptococcus mutans in human fissure decay. Infection and Immunity 26 , 498-507.

MCKeE, A. S., McDermid, A. S., Marsh, P. D. \& ELLwOoD, D. C. (1984). The application of contin- 
uous culture techniques to the study of oral anaerobes. In Models of Anaerobic Infection, pp. 165-175. Edited by M. Hill, S. P. Borriello, J. M. Hardie, M. J. Hudson, R. L. Lysons \& S. Tabaqchali. Dordrecht: Martinus Nijhoff.

Marsh, P. D. \& Martin, M. (1984). Oral Microbiology, 2nd edn. Wokingham: van Nostrand Reinhold.

Marsh, P. D., Williamson, M. I., Keevil, C. W., McDermid, A. S. \& Ellwood, D. C. (1982). The influence of sodium and potassium ions on acid production by washed cells of Streptococcus mutans Ingbritt and Streptococcus sanguis NCTC 7865 grown in a chemostat. Infection and Immunity 36, 476-483.

Marsh, P. D., Hunter, J. R., Bowden, G. H., Hamilton, I. R., McKeE, A. S., Hardie, J. M. \& ELLwood, D. C. (1983). The influence of growth rate and nutrient limitation on the microbial composition and biochemical properties of a mixed culture of oral bacteria grown in a chemostat. Journal of General Microbiology 129, 755-770.

Marsh, P. D., Keevil, C. W. \& Ellwood, D. C. (1984). Relationship of bioenergetic processes to the pathogenic properties of oral bacteria. Journal of Dental Research 63, 401-406.
St Martin, E. J. \& Wittenberger, C. L. (1979). Regulation and function of sucrose 6-phosphate hydrolase in Streptococcus mutans. Infection and Immunity 26, 487-491.

Slee, A. M. \& Tanzer, J. M. (1980). Effect of growth conditions on sucrose phosphotransferase activity of Streptococcus mutans. Infection and Immunity 27, 922-927.

Tanzer, J. M., Freedman, M. L., Woodiel, F. N., Eifert, R. L. \& Rinehimer, L. A. (1976). Association of Streptococcus mutans virulence with synthesis of intracellular polysaccharide. In Microbial Aspects of Dental Caries 3, pp. 597-616. Edited by H. M. Stiles, W. J. Loesche and T. C. O`Brien. Washington, DC: Information Retrieval.

VAN HouTE, J. (1980). Bacterial specificity in the etiology of dental caries. International Dental Journal 30, 305-326.

West, A. A., Keevil, C. W., Marsh, P. D. \& Ellwood, D. C. (1984). The effect of ionophores on growth and glycosyltransferase production of Streptococcus sanguis. FEMS Microbiology Letters 25, $133-137$. 